\title{
Effect of the litter layer on runoff and evapotranspiration using the paired watershed method
}

\author{
Mie Gomyo ${ }^{1}$ (i) $\cdot$ Koichiro Kuraji ${ }^{2}$
}

Received: 27 March 2015/Accepted: 12 July 2016/Published online: 4 October 2016

(c) The Author(s) 2016. This article is published with open access at Springerlink.com

\begin{abstract}
The litter layer on a forest floor can influence both short-term runoff and long-term water balance through modification of various hydrological processes. In this study, we have quantified the watershed-scale effects of the litter layer on runoff and evapotranspiration using a paired watershed method. The removal of the litter layer in a forested watershed with an area of 1.19 ha was conducted annually over the latter half of a 6-year experimental period. An adjacent forested watershed with an area of 1.42 ha was preserved as a control. Our results indicated that litter removal increased the 3-year runoff by $80.3 \mathrm{~mm}$ during the post-treatment period. Furthermore, when the peak flow range in the control watershed was $0.4-1.0 \mathrm{~mm} / \mathrm{h}$ and $>1.0 \mathrm{~mm} / \mathrm{h}$, peak runoff during flood events was about 1.5 and 1.4 times greater than that observed before litter layer removal, respectively. These data suggest that litter layer removal can decrease litter layer interception and, hence, increase peak flow, particularly during relatively large flood runoff events.
\end{abstract}

Keywords Interception - Litter layer - Paired watershed method - Water balance

Mie Gomyo

gomyo@uf.a.u-tokyo.ac.jp

1 Ecohydrology Research Institute, The University of Tokyo Forests, Graduate School of Agricultural and Life Sciences, The University of Tokyo, 11-44 Goizuka, Seto, Aichi 489-0031, Japan

2 The University of Tokyo Chiba Forest, Graduate School of Agricultural and Life Sciences, The University of Tokyo, 299-5503, Amatsu, Kamogawa, Chiba, Japan

\section{Introduction}

There has been a recent decline in harvesting of natural and cultivated forests in developed countries due to the lack of sufficient economic incentive to produce conventional forest products (Onda et al. 2010; Molina and del Campo 2012). Consequently, their woody biomass is increasing and their litter layers are thickening. These forests can exacerbate evapotranspiration (ET) and contribute to a decrease in runoff from forested watersheds (Gallart and Llorens 2003; Komatsu et al. 2015). If this decrease occurs mainly during flood runoff events, flood mitigation could be positively affected; however, if the loss of runoff occurs mainly via the baseflow, this could have negative impacts on the management of water resources.

Three components of ET occur in forests: transpiration by vegetation (35-80\% of ET), rainfall interception by the canopy (10-50\% of precipitation), and forest floor evaporation (10-50\% of throughfall). Of these, forest floor evaporation, which consists of litter layer interception and soil surface evaporation, has received relatively little attention in the literature (Gerrits et al. 2007; Li et al. 2013). Quantifying forest floor evaporation and the effect that the litter layer has on runoff and ET is, therefore, important for managing forests, flood runoff mitigation, and water resources.

A litter layer is typically composed of dead leaves, twigs, small branches, and other fragmented organic material, and has various influences on the hydrological processes that operate in a forested watershed. For example, the litter layer intercepts throughfall and stemflow during periods of rainfall, and causes evaporation during and after them (Hattori 1993; Sato 2007; Gerrits and Savenije 2011; Li et al. 2013). The litter layer covers the ground surface and thus suppresses ground surface evaporation during dry periods (Majima et al. 1990; Murai 
1993). In addition, it mitigates the impact energy of raindrops on throughfall, thereby increasing permeability and reducing overland flow (Walsh and Voigt 1977); however, it also creates a rapid-flow component within the litter layer (Okunishi 1963; Walsh and Voigt 1977; Lee and Shibano 1990). The simultaneous operation of these processes causes the litter layer to affect both short-term runoff and long-term water balance within the hydrological cycle.

Previous studies into the effects of the litter layer on runoff and water balance have been limited to individual hydrological processes; for example, by examining the water-holding capacity of the litter layer in order to estimate the factors that control litter interception (Sato et al. 2004; Rao and Zhu 2007; Zhang et al. 2009; Li et al. 2013). Continuous field measurements of litter interception can only be obtained using a sheet-shaped weighing lysimeter (Schaap and Bouten 1997; Gerrits et al. 2007, 2010) or a permeable basin with a tipping bucket rain gauge to continuously monitor the water that drains from the litter layer into the soil (Bulcock and Jewitt 2012). However, these measuring devices are difficult to establish on sloping surfaces because the overlying litter can move downslope under the influence of gravity, which can alter the impact of raindrops on the forest floor. For this reason, all previous studies using these devices have implemented them on flatlying ground. Moreover, uncertainties arise in extrapolating results obtained from a small flat area to an entire watershed, as the latter includes flat land, slopes, ridges, and the riparian zone. Micro-meteorological conditions, litterfall, and litter decomposition rate differ depending on the topography of each area. In addition, although the flow of streamwater away from a watershed can be measured, it is difficult to measure the groundwater flux from a small flat area to beyond its boundary. As far as the authors are aware, no watershed-scale research has been undertaken on the links between the litter layer, runoff, and ET.
The objective of this study was to quantify the effects of the litter layer on runoff and ET using the paired watershed method (Bosch and Hewlett 1982; Brown et al. 2005; Dung et al. 2012; Komatsu et al. 2012). To achieve this, we analyzed raw data obtained from an experiment in which the litter layer was removed annually from an entire watershed, from 1954 through 1956. The novelty of this research is to quantify the changes in stream runoff and ET before and after mechanical removal of the litter layer on the watershed scale.

\section{Materials and methods}

\section{Study sites}

The paired study sites documented herein comprised two small watersheds: North Creek (NC; watershed area 1.19 ha) and South Creek (SC; 1.42 ha), which are located in the Shirasaka Experimental Watershed $\left(35^{\circ} 13^{\prime} 07^{\prime \prime} \mathrm{N}\right.$, $\left.137^{\circ} 09^{\prime} 54^{\prime \prime} \mathrm{E}\right)$ in the Akazu Research Forest of the Ecohydrology Research Institute (ERI), The University of Tokyo Forests (Fig. 1; Yamaguchi 1963; ERI 2013). Meteorological data collected in an open field located approximately $240 \mathrm{~m}$ west-northwest of the outlet of the NC watershed indicate that the annual average temperature between 1935 and 2014 was $12.4{ }^{\circ} \mathrm{C}$, and the annual average rainfall between 1930 and 2014 was $1861 \mathrm{~mm} /$ year (Gomyo and Kuraji 2013; Kuraji and Gomyo 2014; data missing in 2005). The bedrock in both watersheds is deeply weathered Cretaceous granite. Their elevations are 320-348 $\mathrm{m}$ above sea level and they have slope gradients in the range $3.3-40.8^{\circ}$.

In the 1950s, both watersheds' vegetation comprised mixed forests of Japanese red pine (Pinus densiflora) and deciduous broadleaved trees, mainly konara oak (Quercus
Fig. 1 a Locations of the Shirasaka experimental watershed and $\mathbf{b}$ topography of the North Creek (NC) and South Creek (SC) watersheds

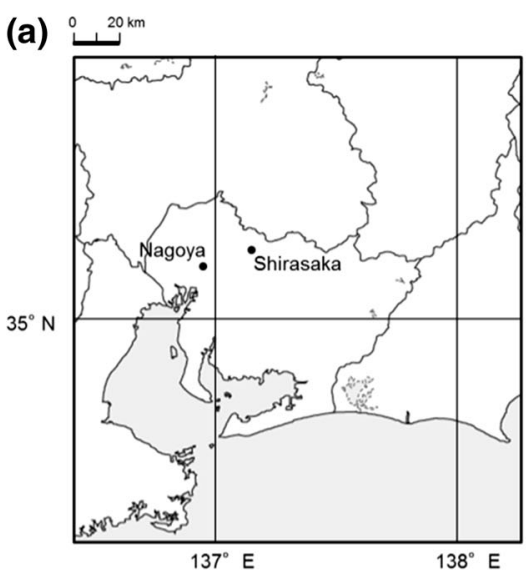

(b)

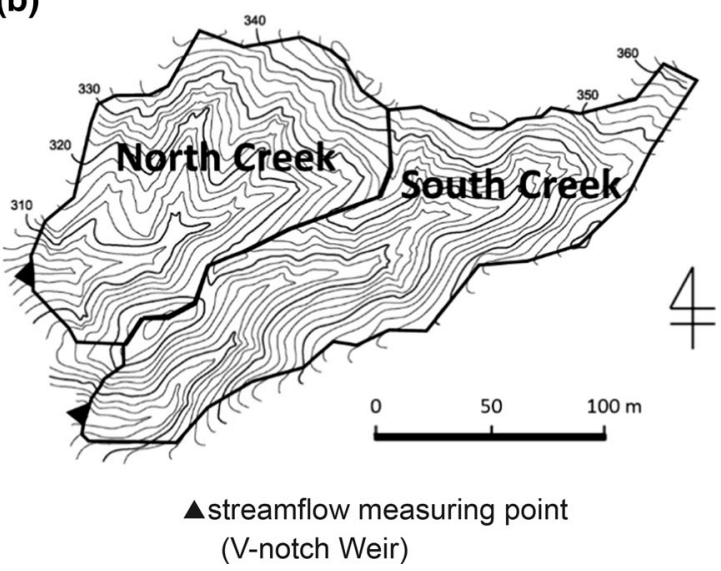


serrata). The highest Japanese red pine and konara oak trees were 28 and $16 \mathrm{~m}$, respectively. In 1954, all trees were measured within 4-m-wide belt transects across both watersheds. Within these areas, the basal area (BA) of Japanese red pine and deciduous broadleaved trees accounted for 54 and $40 \%$ of the BA of all trees in the NC watershed, and 43 and $45 \%$ of those in the SC watershed, respectively (Kataoka et al. 1954).

Litter removal experiments were conducted on three occasions: January 6-15, 1954; January 6-15, 1955; and January 9-13, 1956. All litter from the NC watershed was removed and weighed onsite, whereas the SC watershed was preserved as a control. The weights of litter removed each year from NC are shown in Table 1. The raw data (field notes) produced during these experiments have since been maintained in good condition by the ERI.

\section{Hydrological observations}

Precipitation in the field was measured at the above-mentioned meteorological observation station using a storagetype rain gauge (20-cm diameter) and a siphon rain gauge (20-cm diameter). The storage-type rain gauge was examined every day at 09:00 local time (LT) where a cylinder was used to measure the volume of water collected in a storage bottle within the gauge. This result was considered the rainfall amount for each day beginning at 09:00 LT. At the siphon rain gauge, recording paper that covered the events of a single day was read at 09:00 LT to determine whether rainfall had occurred during the previous $24 \mathrm{~h}$; if any rainfall had been recorded, the paper was replaced. Hourly rainfall data used in this work were read from the original recording papers, which were maintained in good condition by the ERI, and then corrected such that the 24-h rainfall matched the value obtained from the storage-type rain gauge.

Runoff was observed using weirs installed at the outlets of the watersheds. Each weir consisted of a stilling pool $\left(6.0 \times 9.7 \mathrm{~m}\right.$ in the $\mathrm{NC}$ and $6.0 \times 9.0 \mathrm{~m}$ in the SC), a $60^{\circ}$ $\mathrm{V}$-notch weir, an automatic recording water-level gauge, and a point gauge. The recording paper from the water- level gauge covered a 1-day period and was replaced daily at 09:00 LT. The values from the point gauge were read and recorded on the original recording paper, which were maintained in good condition by the ERI and subsequently examined in this work. Any changes in water level recorded on the recording paper were noted at 1-min intervals. Assuming a linear change in the water level between adjacent points over time, the equation used to calculate flow rate based on the water level was integrated over time to calculate the runoff during this period. These values were then summed each day to obtain the daily runoff. The following formula was used to calculate the runoff based on the water levels at the NC and SC watersheds:

$Q=\alpha H^{2.5}$

where $Q$ is runoff $\left[\mathrm{m}^{3} / \mathrm{s}\right], H$ is water level [m], and $\alpha$ is the coefficient of runoff determined by the observation of $Q$ and $H$ (NC watershed: 0.7669, SC watershed: 0.8086).

In this study, the pre- and post-treatment periods were 1951-1953 and 1954-1956, respectively. There were no missing daily rainfall measurements, but daily runoff measurements were missing in the $\mathrm{NC}$ watershed for 2 days in 1951, 3 days in 1953, 4 days in 1954, 9 days in 1955, and 2 days in 1956, as well as for 3 days in the SC watershed in 1955. To address these data gaps in each watershed, we multiplied the available daily runoff measurement in the other watershed on the date of the missing data by the ratio of the daily runoff in the $\mathrm{NC}$ and $\mathrm{SC}$ watersheds on the day before or after that of the missing data. In 1955, there was 1 day on which measurements were missing for both watersheds, although no precipitation occurred; thus, the missing measurements were complemented with the average of the daily runoffs recorded on the previous and following days.

\section{Paired watershed method}

To evaluate the effect of litter removal on the annual runoff in the NC watershed, we estimated the annual runoff during the post-treatment period under the assumption that
Table 1 Date, number of days and total weight of litter removed from the North Creek watershed

\begin{tabular}{lllll}
\hline Year & Date & Number of days & Litter weight $\left(\times 10^{4} \mathrm{~kg}\right)$ & Litter weight $\left(\mathrm{kg} \mathrm{m}^{-2}\right)$ \\
\hline 1954 & 7-12, 14-15 January* & 8 & 1.800 & 1.5 \\
1955 & 10-14 January & 5 & 1.170 & 1.0 \\
1956 & 9-13 January & 5 & 1.465 & 1.2 \\
\hline
\end{tabular}

The litter weight removed in 1954 was the litterfall before December 1953 (long-term) minus litter decomposed during the same period

Litter weights removed in January 1955 and 1956 were the litterfall from January 1954 to December 1955 ( 1 year) minus litter decomposed during the same period and the litterfall from January 1955 to December 1956 (1 year) minus litter decomposed during the same period, respectively

* No work on 13 January 1954 due to rainy weather 
treatment had not occurred $\left(Q_{\mathrm{ENA}}\right)$. A linear regression equation between the annual observed runoff in the $\mathrm{NC}$ and $\mathrm{SC}$ watersheds during the pre-treatment period was used:

$Q_{\mathrm{NB}}=a \times Q_{\mathrm{SB}}+b$,

where $Q_{\mathrm{NB}}$ and $Q_{\mathrm{SB}}$ are the annual observed runoffs in the $\mathrm{NC}$ and SC watersheds during the pre-treatment period, respectively, and $a$ and $b$ are regression coefficients. We then estimated $Q_{\mathrm{ENA}}$ by the following equation:

$Q_{\mathrm{ENA}}=a \times Q_{\mathrm{SA}}+b$,

where $Q_{\mathrm{SA}}$ is the annual observed runoff in the SC watershed during the post-treatment period, and $a$ and $b$ are the regression coefficients determined by Eq. (2).

\section{Magnitude of peak flow}

We detected how the magnitude of peak flow during storm events changed between the pre- and post-treatment periods by tabulating data from all storm events with a peakflow magnitude at the SC control watershed $\left(Q_{\mathrm{PS}}\right)$ greater than $0.1 \mathrm{~mm} / \mathrm{h}(=0.028 \mathrm{~L} / \mathrm{s} / \mathrm{ha}$; Harr and McCorison 1979). If one event with the lag time between the timing of the peak flow in the NC and SC was $<60 \mathrm{~min}$, the event was rejected because the rainfall peaks that corresponded to peak flows in the SC and NC may have been different. In total, 41 and 66 peak flow events that met this definition were identified during the pre- and post-treatment periods, respectively. The ratio of the magnitude of peak flow in the NC watershed $\left(Q_{\mathrm{PN}}\right)$ and $Q_{\mathrm{PS}}$ (hereafter, referred to as "peak flow ratio") was compared between the pre- and post-treatment periods. To identify the statistical significance of the difference between the pre- and post-treatment periods, we applied an analysis of covariance (ANCOVA). Peak flows were log-transformed to meet the assumption of homoscedasticity and to improve the frequency distribution of the data along the interval of the regression (Wright et al. 1990). The significances of the regression relationship and parallelism were tested before testing for different intercepts.

\section{Results}

\section{Observed hydrograph}

The 6-year hyeto-hydrographs observed at daily intervals in the NC and SC watersheds are shown in Fig. 2a, b, respectively. The runoff from both watersheds was similar; however, the observed peak daily runoff in the $\mathrm{NC}$ watershed $\left(Q_{\mathrm{ON}}\right)$ tended to be greater than that in the SC watershed $\left(Q_{\mathrm{OS}}\right)$ during the pre- and post- treatment periods. Because their rainfall-runoff responses were

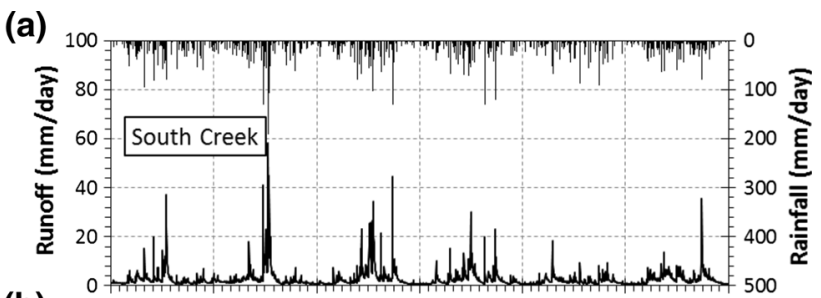

(b)
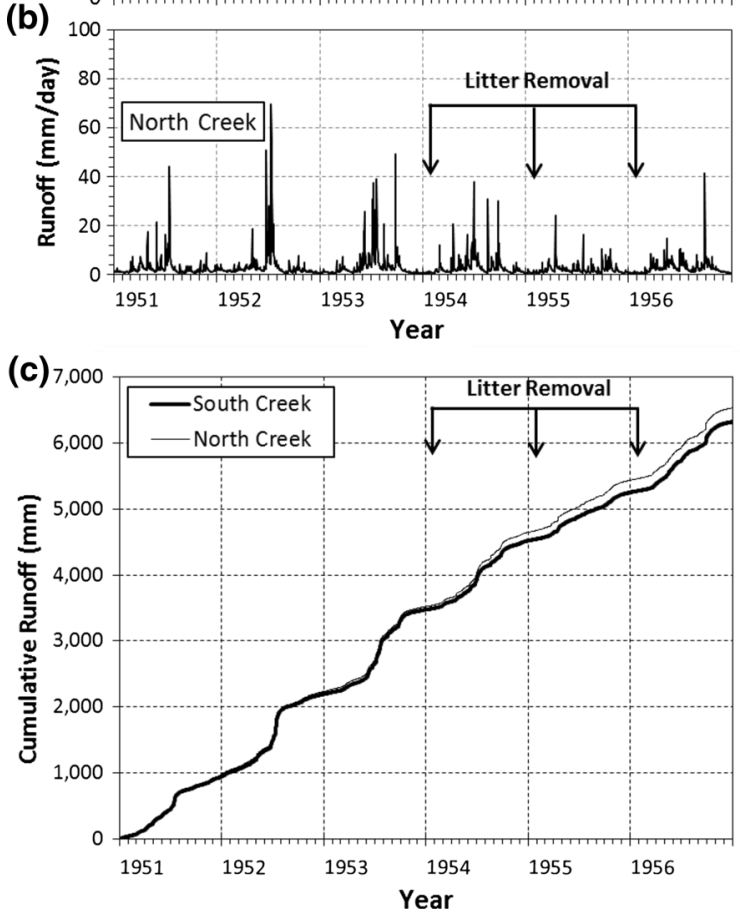

Fig. 2 6-year hyeto-hydrograph at daily intervals observed in a the North Creek (NC) watershed, b the South Creek (SC) watershed, and c 6-year cumulative runoff in the $\mathrm{NC}$ and $\mathrm{SC}$ watersheds

similar (the correlation coefficients between $Q_{\mathrm{ON}}$ and $Q_{\mathrm{OS}}$ during the pre- and post-treatment periods were 0.986 and 0.980 , respectively), the paired watershed method was considered appropriate. The 6-year cumulative $Q_{\mathrm{ON}}$ and $Q_{\mathrm{OS}}$ curves are shown in Fig. 2c. There was no clear difference between the cumulative $Q_{\mathrm{ON}}$ and $Q_{\text {os }}$ during the pre-treatment period, whereas the cumulative $Q_{\mathrm{ON}}$ was greater than the cumulative $Q_{\mathrm{OS}}$ during the post-treatment period.

\section{Annual water balance}

Annual precipitation, annual runoff in the $\mathrm{NC}$ and SC watersheds, and the difference between the annual runoff in the NC and SC watersheds are shown in Table 2. The pretreatment 3-year $Q_{\mathrm{ON}}$ was $46.1 \mathrm{~mm}$ greater than the 3-year $Q_{\mathrm{OS}}$, whereas the post-treatment 3-year $Q_{\mathrm{ON}}$ was $163.2 \mathrm{~mm}$ greater than the 3 -year $Q_{\mathrm{os}}$.

From Eqs. (2) and (3), the annual runoff in the NC watershed during the post-treatment period that would be 
Table 2 Annual and 3-year precipitation, runoff, and difference between the North Creek (NC) and South Creek (SC) watersheds during the pre- and post-treatment periods, and estimated annual and 3-year runoff, and differences between the estimated and observed annual runoffs in the $\mathrm{NC}$ watershed during the post-treatment period

\begin{tabular}{|c|c|c|c|c|c|c|}
\hline \multirow{2}{*}{$\frac{\text { Year }}{\text { Pre-treatment period }}$} & \multirow[t]{2}{*}{ Precipitation (mm) } & \multicolumn{2}{|c|}{ Discharge $(\mathrm{mm})$} & \multirow{2}{*}{$\frac{\text { Difference }(\mathrm{mm})}{Q_{\mathrm{NB}}-Q_{\mathrm{SB}}}$} & \multirow[t]{2}{*}{ Estimated discharge (mm) } & \multirow[t]{2}{*}{ Difference $(\mathrm{mm})$} \\
\hline & & $Q_{\mathrm{SB}}$ & $Q_{\mathrm{NB}}$ & & & \\
\hline 1951 & 1906.4 & 945.1 & 972.8 & 27.7 & & \\
\hline 1952 & 2176.4 & 1249.8 & 1262 & 12.2 & & \\
\hline 1953 & 2123.4 & 1281.9 & 1288.1 & 6.2 & & \\
\hline $1951-53$ & 6206.2 & 3476.7 & 3522.8 & 46.1 & & \\
\hline Post-treatment period & & $Q_{\mathrm{SA}}$ & $Q_{\mathrm{NA}}$ & $Q_{\mathrm{NA}}-Q_{\mathrm{SA}}$ & $Q_{\text {ENA }}$ & $Q_{\mathrm{ENA}}-Q_{\mathrm{NA}}$ \\
\hline 1954 & 2063.8 & 1044.4 & 1124.2 & 79.8 & 1066.5 & 57.7 \\
\hline 1955 & 1690.7 & 734.1 & 790.7 & 56.6 & 774.4 & 16.3 \\
\hline 1956 & 1941.7 & 1070.5 & 1097.3 & 26.8 & 1091.0 & 6.3 \\
\hline $1954-56$ & 5696.2 & 2849.0 & 3013.1 & 163.2 & 2931.9 & 80.3 \\
\hline
\end{tabular}

Fig. 3 a Relationship between peak flow in the South Creek (SC) and North Creek (NC) watersheds during the pre- and post-treatment periods. b Average of the peak flow ratio (error bars indicate one standard deviation)
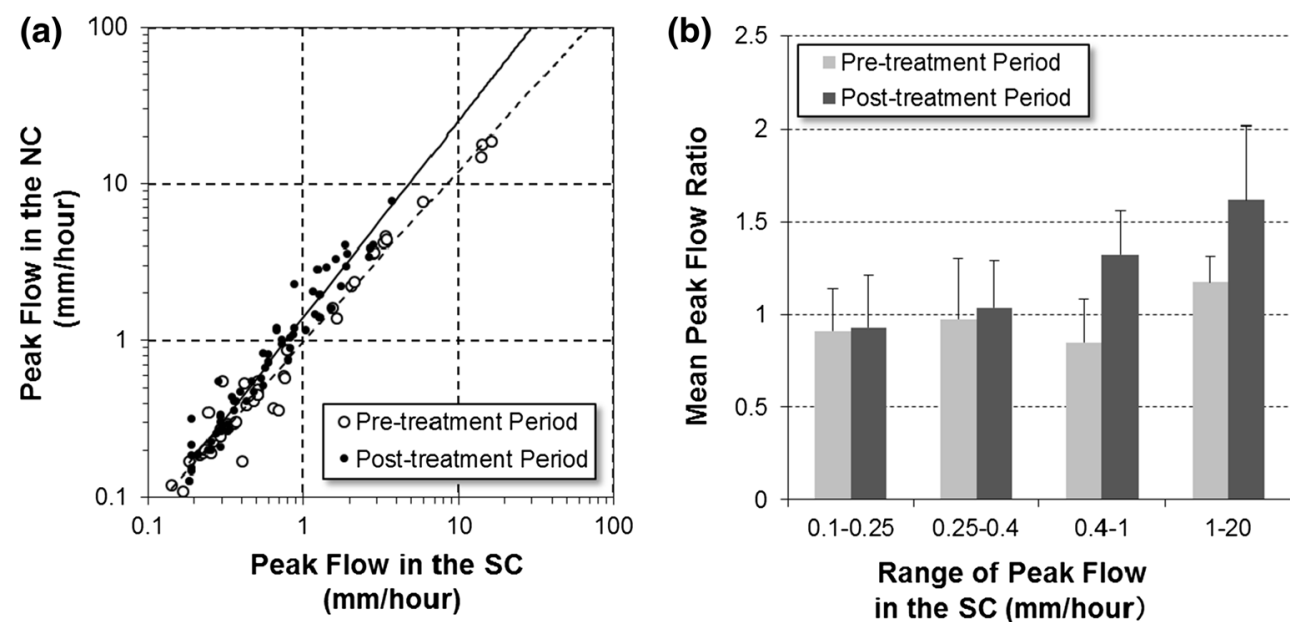

Table 3 Result of ANCOVA for the treatment effect

\begin{tabular}{lccccc}
\hline Range of $\mathrm{Q}_{\mathrm{PS}}(\mathrm{mm} / \mathrm{h})$ & Pre-treatment, $N$ & Post-treatment, $n$ & Regression $p$ & Parallelism $p$ & Intercept $p$ \\
\hline $0.1-0.25$ & 8 & 9 & $0.009^{*}$ & 0.757 & 0.764 \\
$0.25-0.4$ & 7 & 20 & $0.005^{*}$ & 0.364 & 0.643 \\
$0.4-1.0$ & 13 & 19 & $p<0.001 *$ & 0.185 & $p<0.001^{*}$ \\
$>1.0$ & 13 & 18 & $p<0.001^{*}$ & 0.669 & $p<0.001^{*}$ \\
\hline
\end{tabular}

Note that the regression $p$ indicates there is a significant regression relationship with the covariance and the parallelism $p$ indicates the regression lines for these individual groups are assumed to be non-parallel; in other words, they have the different slope. The intercept $p$ indicates the intercept of the regression line for these individual groups are assumed to be different

* Significant with $\alpha=0.01$ expected in the absence of treatment $\left(Q_{\mathrm{ENA}}\right)$ was obtained by the following equation:

$Q_{\mathrm{ENA}}=0.94 \times Q_{\mathrm{SA}}+83.3, R^{2}=0.9999$

where $Q_{\mathrm{SA}}$ is the annual runoff in the SC watershed during the post-treatment period ( $\mathrm{mm} /$ year).

The $Q_{\mathrm{ENA}}$ for 1954,1955 , and 1956 (Table 2) was 57.7, 16.3 , and $6.3 \mathrm{~mm}$ less than the annual runoff in the NC watershed during the post-treatment period $\left(Q_{\mathrm{NA}}\right)$ for the same years, respectively, indicating that litter removal increased the annual runoff in the NC watershed. The 3 -year total runoff increased by $80.3 \mathrm{~mm}$ during the posttreatment period.

\section{Magnitude of peak flow}

Figure 3a shows the relationship between the $Q_{\mathrm{PN}}$ and $Q_{\mathrm{PS}}$ during the pre- and post-treatment periods. Although there 
is scattering, the $Q_{\mathrm{PN}}$ during the post-treatment period was larger than during the pre-treatment period. Figure $3 \mathrm{~b}$ shows the average peak flow ratio obtained for four $Q_{\mathrm{PS}}$ ranges during the pre- and post-treatment periods. The results of ANCOVA are shown in Table 3. No significant difference in the peak flow ratio was detectable between the pre- and post-treatment periods when the $Q_{\mathrm{PS}}$ range was $0.1-0.25$ or $0.25-0.4 \mathrm{~mm} / \mathrm{h}$; however, the peak flow ratio of the post-treatment period was greater than that in the pre-treatment period when the $Q_{\mathrm{PS}}$ range was $0.4-1.0$ or $>1.0 \mathrm{~mm} / \mathrm{h}$. For the $Q_{\mathrm{PS}}$ range of $0.4-1.0 \mathrm{~mm} / \mathrm{h}$, the post-treatment peak flow ratio was 1.46 , which is about 1.5 times that of the pre-treatment period (0.98). In addition, the post-treatment peak flow ratio was 1.81 during a flood event when the $Q_{\mathrm{PS}}$ range was $>1.0 \mathrm{~mm} / \mathrm{h}$, which is about 1.4 times that of the pre-treatment period (1.29). The treatment effect on the $Q_{\mathrm{PN}}$ was statistically significant when the $Q_{\text {PS }}$ range was $>0.4 \mathrm{~mm} / \mathrm{h}$ (ANCOVA, Table 3 ).

\section{Discussion}

\section{Effect of litter removal on ET}

This paired watershed experiment showed that litter removal increased the 3-year total runoff in the $\mathrm{NC}$ watershed by $80.3 \mathrm{~mm}$. Thus, the annual loss of water decreased, as calculated by subtracting annual runoff from annual precipitation. The difference between the annual loss of water and annual ET is the difference in watershed water storage between the start and the end dates of the study period, alongside deep percolation that cannot be measured by a weir (Oda et al. 2008). We estimate that litter removal reduced the annual ET because the difference in watershed water storage might be smaller compared with the 3-year precipitation, runoff, and ET. Although about $5 \%$ of the annual precipitation could possibly have been deep percolation in this study site (Terajima et al. 1993), we suggest that the impact of litter removal on deep percolation might be negligible compared with the impact on runoff and ET.

The observed decrease in annual ET caused by litter removal implies that the presence of a litter layer enhances ET from a forested watershed. One possible mechanism to explain this result could be that the increase in litter interception exceeded the reduction in soil surface evaporation.

Previous studies have suggested that differences in litter weight, rainfall intensity and frequency, and evaporative demand of the forest floor could cause large variations in the volume of forest floor interception and the proportion of throughfall (Gerrits and Savenije 2011; Zagyvainé Kiss et al. 2014). Helvey (1967) reported annual litter interception amounts of 30, 46, and $56 \mathrm{~mm}$ in 10-, 30-, and 60-year-old stands of eastern white pine (Pinus strobus), respectively, in which the annual rainfall was about $1500 \mathrm{~mm}$ and the litter weight was $1.2 \mathrm{~kg} / \mathrm{m}$ (similar to our study: $1.0-1.5 \mathrm{~kg} / \mathrm{m}$ ). The forest type in Helvey's study was similar to that of ours, and the estimated decrease in 3-year ET in our study $(80.3 \mathrm{~mm})$ is comparable with that reported by Helvey (1967), which suggests that forest floor evaporation could be accounted for by the decrease in litter interception after litter removal from the entire watershed. Bulcock and Jewitt (2012) reported 3-year litter interceptions of 160, 125, and $231 \mathrm{~mm}$ in Eucalyptus, Acacia, and Pinus stands, respectively. These values are also comparable with those of our study. The litter weights reported by Bulcock and Jewitt (2012; 2.3, 2.4, and $3.3 \mathrm{~kg} / \mathrm{m}$ for $\mathrm{Eu}$ calyptus, Acacia, and Pinus stands, respectively) were about two or three times greater than our study $(1.0-1.5 \mathrm{~kg} / \mathrm{m})$. The comparable value of litter interception between our study and Bulcock and Jewitt (2012) may be the difference of rainfall condition. The 3-year rainfall for the study period of Bulcock and Jewitt (2012) was 1885-1910 mm, which is about one-third of that in our study period ( $5696.2 \mathrm{~mm} /$ three-year during the post-treatment period). Thus, the decrease in ET identified herein is comparable with that of previous stand-scale studies; however, because of the rarity of such work, we cannot conclude that the observed forest floor evaporation is consistent at all observational scales (i.e., watershed- or stand-scale studies).

\section{Peak flow}

Figure 3 shows that the peak flow ratio was greater in the post-treatment period than in the pre-treatment period, with the degree varying according to the scale of the flood event.

The effects of a litter layer on runoff in a forested watershed are the occurrence of a rapid-flow component within the litter layer, litter interception, mitigation of the impact of raindrops, suppression of surface flow, and an increase in permeability (Walsh and Voigt 1977). The rapid-flow component within the litter layer increases the peak flow, whereas the other factors might act to reduce it.

The $Q_{\mathrm{PN}}$ during the post-treatment period had relatively little impact for relatively small events $\left(Q_{\mathrm{PS}}\right.$ range of $<0.4 \mathrm{~mm} / \mathrm{h}$ ), and the presence or absence of litter had almost no effect on the peak runoff quantity during flood events within this range. By contrast, the removal of litter increased the peak flow by 1.4-1.5 times for relatively greater flood events $\left(Q_{\mathrm{PS}}\right.$ range of $\left.>0.4 \mathrm{~mm} / \mathrm{h}\right)$. For flow events with a $Q_{\mathrm{PS}}$ range of $<0.4 \mathrm{~mm} / \mathrm{h}$, either the increased and decreased effects of the litter layer on the peak flow were offset, or both effects could have been insignificant. However, for flood events with a $Q_{\mathrm{PS}}$ range of $>0.4 \mathrm{~mm} / \mathrm{h}$, the effects on peak flow reduction by the litter layer (litter 
interception, raindrop impact mitigation, overland flow suppression, permeability increase; Walsh and Voigt 1977) were remarkably stronger than its effect on the $Q_{\mathrm{PN}}$ increase. Thus, at least in this study, the loss of these effects in relation to litter removal probably induced the peak flow increase.

\section{Conclusions}

A paired watershed method was applied in this study to identify how a litter layer controls runoff and evapotranspiration. Approximately $4.4 \times 10^{4} \mathrm{~kg}$ of litter was removed from the forest floor of an entire watershed for three consecutive years, which increased the 3 -year runoff by a total of $80.3 \mathrm{~mm}$. Results showed that the peak runoff during a large flood event was $\sim 1.4-1.5$ times greater due to removal of the litter layer; indeed, increased runoff due to litter layer removal occurred mainly during such flood events. If a litter layer exists in a plantation forest, its removal may have a negative impact on flood mitigation, but a positive impact on water resource management. Conversely, in a plantation forest from which a litter layer has been lost, its recovery may have a positive impact on flood mitigation, but a negative impact on water resource management. Further observational and modeling studies are necessary to clarify the role of a litter layer on the processes and mechanisms of runoff during flood events, and to evaluate the impact of the increase or decrease of litter volume on flood mitigation measures and water resources management.

Acknowledgments We thank Yoshie Gomyo (project specialist) and Junko Kato (project academic support staff) for their support of this study. The authors express their appreciation to the Ecohydrology Research Institute, The University of Tokyo Forests, and the Graduate School of Agricultural and Life Sciences at The University of Tokyo for their continuous support of our activities. We acknowledge the two anonymous reviewers for providing helpful comments on an initial version of this manuscript. We would like to thank Editage (www.editage.jp) for English language editing.

\section{Compliance with ethical standards}

Funding This study was funded by the Japan Society for the Promotion of Science KAKENHI (Grant Number 25.6722).

Conflict of interest The authors declare that they have no conflict of interest.

Open Access This article is distributed under the terms of the Creative Commons Attribution 4.0 International License (http://crea tivecommons.org/licenses/by/4.0/), which permits unrestricted use, distribution, and reproduction in any medium, provided you give appropriate credit to the original author(s) and the source, provide a link to the Creative Commons license, and indicate if changes were made.

\section{References}

Bosch JM, Hewlett JD (1982) A review of catchment experiments to determine the effect of vegetation changes on water yield and evapotranspiration. J Hydrol 55:3-23

Brown AE, Zhang L, McMahon TA, Western AW, Vertessy RA (2005) A review of paired catchment studies for determining changes in water yield resulting from alterations in vegetation. J Hydrol 310:28-61

Bulcock HH, Jewitt GPW (2012) Field data collection and analysis of canopy and litter interception in commercial forest plantations in the KwaZulu-Natal Midlands, South Africa. Hydrol Earth Syst Sci 16:3717-3728

Dung BX, Gomi T, Miyata S, Sidle RC, Kosugi K, Onda Y (2012) Runoff responses to forest thinning at plot and catchment scales in a headwater catchment draining Japanese cypress forest. J Hydrol 444-445:51-62

ERI (Ecohydrology Research Institute) (2013) Several reports in 1955 on water-level measurements at four gauging stations of Ananomiya, Higashiyama, Kazunari, and Shirasaka. Bull Univ Tokyo For 53:129-152 (in Japanese with English abstract)

Gallart F, Llorens P (2003) Observations on land cover changes and water resources in the headwaters of the Ebro catchment, Iberian Peninsula. Phys Chem Earth 29:769-773

Gerrits AMJ, Savenije HHG (2011) Forest floor interception: forest hydrology and biogeochemistry: synthesis of past research and future directions. Ecol Stud 216:445-454

Gerrits AMJ, Savenije HHG, Hoffmann L, Pfister L (2007) New technique to measure forest floor interception-an application in a beech forest in Luxembourg. Hydrol Earth Syst Sci 11:695-701

Gerrits AMJ, Pfister L, Savenije HHG (2010) Spatial and temporal variability of canopy and forest floor interception in a beech forest. Hydrol Process 24:3011-3025

Gomyo M, Kuraji K (2013) Long-term variation of annual loss and annual evapotranspiration in small watershed with the forest restoration and succession on denuded hills. J Jpn For Soc 95:109-116 (in Japanese with English abstract)

Harr RD, McCorison FM (1979) Initial effects of clearcut logging on size and timing of peak flows in a small watershed in Western Oregon. Water Resour Res 15:90-94

Hattori S (1993) Forest and evapotranspiration. In: Japan Society of Erosion Control Engineering (ed) Soil erosion, water discharge and forest influence. Sankaido Co. Ltd, Tokyo, pp 171-198 (in Japanese)

Helvey JD (1967) Interception by eastern white pine. Water Resour Res 3:723-729

Kataoka J, Takasugi K, Akiya K (1954) unpublished manuscript (in Japanese)

Komatsu H, Jaeil C, Matsumoto K, Otsuki K (2012) Simple modelling of the global variation in annual forest evapotranspiration. J Hydrol 420-421:380-390

Komatsu H, Shinohara Y, Otsuki K (2015) Models to predict changes in annual runoff with thinning and clearcutting of Japanese cedar and cypress plantations in Japan. Hydrol Process 29:5120-5134. doi:10.1002/hyp. 10520

Kuraji K, Gomyo M (2014) Estimation of the variation of 78 years' mean annual temperature in the Ecohydrology Research Institute of The University of Tokyo Forests, and its relation to the temperature increase in Nagoya caused by urbanization with a correction for instrument error. Bull Univ Tokyo For 131:29-40 (in Japanese with English abstract)

Lee HH, Shibano H (1990) Hydraulic characteristics of storm water flowing through litter layer. J Jpn For Soc 72:223-229 (in Japanese) 
Li X, Niu J, Xie B (2013) Study on hydrological functions of litter layers in north China. PLoS One 8:1-11

Majima M, Kitahara H, Shimizu A (1990) Measurement of water balance at different ground cover with plain lysimeter. Proc Boreal For Soc 38:233-235 (in Japanese)

Molina AJ, del Campo AD (2012) The effects of experimental thinning on throughfall and stemflow: a contribution towards hydrology-oriented silviculture in Aleppo pine plantations. For Ecol Manag 269:206-213

Murai H (1993) Forest soil-function of water and soil conservation. In: Japan Society of Erosion Control Engineering (ed) Soil erosion, water discharge and forest influence. Sankaido Co. Ltd, Tokyo, pp 199-218 (in Japanese)

Oda T, Asano Y, Suzuki M (2008) Estimating deep percolation in a small catchment in a tertiary formation using the chloride mass balance method. J Jpn Soc Hydrol Water Resour 21:195-204

Okunishi K (1963) Rainfall and runoff on mountainside-Part 1. Runoff from fallen-leaf layer. Disaster Prev Res Inst Annu 6:156-165 (in Japanese with English abstract)

Onda Y, Gomi T, Mizugaki S, Nonoda T, Sidle RC (2010) An overview of the field and modelling studies on the effects of forest devastation on flooding and environmental issues. Hydrol Process 24:527-534

Rao L, Zhu J (2007) Hydrological effects of forest litter and soil in the Simianshan Mountains in Chongqing, China. Front For China 2:157-162

Sato Y (2007) Rainfall interception-How to estimate the amount of water reaching to the forest soil. Forest Hydrology-Exploring the fate of water in forest ecosystems. The editing committee of Forest Hydrology, Morikita Publishing Co. Ltd, Tokyo, pp 14-39 (in Japanese)

Sato Y, Kumagai T, Kume A, Otuki K, Ogawa S (2004) Experimental analysis of moisture dynamics of litter layers: the effects of rainfall conditions and leaf shapes. Hydrol Process 18:3007-3018

Schaap MG, Bouten W (1997) Forest floor evaporation in a dense Douglas fir stand. J Hydrol 193:97-113

Terajima T, Mori A, Ishii H (1993) Comparative study of deep percolation amount on two small catchments in granitic mountain. Hydrology (J Jap Assoc Hydrol Sci) 23:105-118 (in Japanese with English abstract)

Walsh RPD, Voigt PJ (1977) Vegetation litter: an underestimated variable in hydrology and geomorphology. J Biogeogr 4:253-274

Wright KA, Sendek KH, Rice RM, Thomas RB (1990) Logging effects on streamflow: storm runoff at Casper Creek in northeastern California. Water Resour Res 26:1657-1667

Yamaguchi I (1963) Fundamental studies on the groundwater flow phenomena at the water source zone. Bull Univ Tokyo For 58:133-285 (in Japanese)

Zagyvainé Kiss KA, Kalicz P, Csáfordi P, Gribovszki Z (2014) Forest litter interception model for a sessile oak forest. Acta Silv Lig Hung 10:91-101

Zhang Z, Lei Y, Su K, Wang G, Wang D, Ma H (2009) Hydrological characteristics of litter in different forest succession stages at Liuxihe Watershed, South China. Front For China 4:317-322 